\title{
KHDRBS3 Gene
}

National Cancer Institute

\section{Source}

National Cancer Institute. KHDRBS3 Gene. NCI Thesaurus. Code C162400.

This gene is involved in exon exclusion. 